\title{
Ecological features of titica vine (Heteropsis flexuosa (Kunth) GS Bunting) in Rondônia State, Northwest Brazilian Amazon
}

\author{
MICHELLINY M. BENTES GAMA, ABADIO H. VIEIRA and RODRIGO B. ROCHA \\ EMBRAPA, Centro de Pesquisa Agroflorestal de Rondônia, \\ BR 364, Km 5,5, Caixa Postal 127, 76815-800 Porto Velho, RO, Brasil \\ Manuscript received on May 6, 2011; accepted for publication on January 10, 2013
}

\begin{abstract}
The aim of this study was to characterize the forest structure with H. flexuosa in Rondônia State, as a first step in developing sustainable harvest and conservation guidelines for the species. Crown attributes, total height $(\mathrm{m})$ and diameter at breast height $\geq 10(\mathrm{~cm})$ of trees and palms with $H$. flexuosa were evaluated in three permanent plots (100 m x $150 \mathrm{~m}$ each) randomized in 219 ha. A total of 22 botanical families hosted H. flexuosa. It was not observed any specific preference for the species standing up itself. Nevertheless it was frequently associated to Burseraceae, Leguminosae, Sapotaceae, Annonaceae, Chrysobalanaceae, Apocynaceae, Moraceae and Myristicaceae and species with thick bark like Schweilera coriacea, Protium sp. and Licania membranaceae. The species was less frequent with taller and broader trees and tended to develop in understory light condition. Trunks or branches were the main position for the attaching of $H$. flexuosa $(90.83 \%)$ and a low frequency of other lianas was observed on the same host trees. These highlight the need to promote appropriate management practices for root harvesting and species conservation in order to maintain the species in open ombrophylus forest habitat.
\end{abstract}

Key words: non-timber forest product, ecology, plant fibers, habitat preference, multiple-use forest management.

\section{INTRODUCTION}

The magnitude and importance of the natural resources in the Amazon tropics have not been properly appreciated to date. Misinformation and disinformation on many patterns and processes involving the diversity and distribution of Amazonian organisms are main factors that cause threats to the wilderness, biodiversity and local people. The open ombrophylus forest in Rondonia State, which encompasses a main biological repository in the Northwestern Brazilian Amazon,

Correspondence to: Michelliny de Matos Bentes Gama

E-mail: michelliny.bentes-gama@embrapa.br covering up to $50 \%$ of upland forest ecosystems in the region, is a current area under threat due to the accelerated development since the 1980's.

Among the ecosystem functions and products that many species and their populations of tropical biodiversity may offer, vegetal fibers may constitute a real opportunity for new markets and incomes for rural communities who rely on fiber extraction and processing. It may in turn contribute to the promotion and development of sustainable non-wood-based regional economies (Shanley et al. 2002).

Some plant fibers such as carauá (Ananas erectifolius), babaçu(Orbignya spp.), buriti (Mauritia 
flexuosa), carnauba (Copernicia prunifera), and piaçava (Attalea funifera) feature in the non-timber economy of many Brazilian rural communities (IBGE 2005). In addition to that, recent studies have demonstrated the potential of these non-wood species for numerous applications (Monteiro et al. 2006a, b, Marques et al. 2007, Zambrana et al. 2007). Still, in the Amazon, little scientific information on major species that could high-value agricultural products is available to develop technical guidelines for sustainable management.

Multi-use approaches to tropical forests invite a great number of possibilities to generate forest goods and services (Fearnside 2008). Nevertheless non-timber forest products (NTFPs) are still far from having clear guidelines on sustainable multiple-use management (Summers et al. 2004, Guariguata et al. 2010).

Beyond encouraging the extraction of the raw material itself in order to expand the use of vegetable fibers in the Amazon, it is necessary to investigate the natural species behavior (Balcázar-Vargas and van Andel 2005, Balcázar-Vargas et al. 2011) to allow improvement in the current harvesting method of non-wood species (Leoni and Marques 2008), for which there are few protective laws or regulations in most of the Brazilian Amazon states.

From a biophysical standpoint, it is important to know more about the mechanisms and patterns by which these species establish themselves in their natural environment. It will contribute in filling the lack of scientific information to support management recommendations regarding the conservation of species of important biological and economic value.

The main concerns regarding non-wood forest species management relates to inadequate removal practices, which can compromise the mechanisms of resilience through the continued removal of their populations. This is the case of titica vine (Heteropsis flexuosa (HBK) GS Bunting), one of the eight natural fibers used in the regional markets of natural products in Rondônia State (Diário... 2010).
Extraction of the species is regulated only in the Brazilian states of Amapá and Amazonas (Amapá 2001, Amazonas 2008); while in the other states $100 \%$ of Heteropsis spp. roots are removed, causing severe damages or death to the mother plant of the vine. Amapá State, actually, is the main producer of Heteropsis sp. in the Amazon Region, with an average monthly production of 45 tons of raw fiber-followed by the states of Pará, Amazonas and Rondônia (IBGE 2005).

The genus Heteropsis encompasses 17 species (Morais 2008) and is described by Plowden et al. (2003) as a hemi-epiphytic root of natural occurrence in most of the Amazon Basin forests. In Rondônia State, at least two species of titica vine are commonly found in the main forest type formation (Heteropsis flexuosa (Kunth) GS Bunting and Heteropsis spruceana Schott). Although the economic use of the fiber may be low in contrast to agricultural income, Heteropsis spp. roots are widely appreciated by their resistance for baskets, furniture and other manual handcrafts, therefore a source of additional income for local communities.

The objective of this study was to characterize the forest structure with $H$. flexuosa in open ombrophylus "terra firme" forest in Rondônia State as a basis for future sustainable harvest and conservation guidelines of the species.

\section{MATERIALS AND METHODS}

\section{STUDY SPECIES}

Titica vine (Heteropsis spp.), Araceae, is found in a variety of Central American (Costa Rica, Nicaragua) and particularly South American (Colombia, Venezuela, Ecuador, Guyana, Perú, Brazil) habitats. In Brazil it ranges from the Amazon to the Atlantic forest (Morais 2008).

The species differs from true epiphytes by germinating in soil. After germination, it commonly uses adventitious root to climb a plant, usually trees, and reach a point where it can growth and receive 
light and nutrients for development. The trees that stand the liana are known as host trees. The vine reaches the juvenile phase when it produces its first large leaf and a vegetative elongation, forming what is commonly called as the vine's "mother plant". To survive, the mother plant sends down an absorbent root, allowing a connection to the ground to transport water and nutrients (Plowden et al. 2003).

The vine usually grows attached to the trunk of the host tree and it is possible to find inflorescences of $H$. flexuosa from $7 \mathrm{~m}$ upwards, with most inflorescences at heights of $>10 \mathrm{~m}$ (Balcázar-Vargas et al. 2011). In addition, when it develops a root with downward growth it may be susceptible to damage by herbivores. When the meristem is damaged, a node can be observed together with the appearance of new roots which will keep on growing until they reach the soil (Plowden et al. 2003, Morais 2008). For commercial purposes, good quality roots should show few nodes and no sign of weevil infestation (Balcázar-Vargas and van Andel 2005). In rural Brazilian communities, the absence of nodes is a main indicator for resistance and durability to the local production (Almeida 2010).

\section{Study Site, SAmple Design ANd Field Measurements}

Fieldwork was conducted during the dry season, in October 2006, at the research station of Embrapa in the municipality of Machadinho do Oeste, Northwestern of Rondônia Sate $\left(61^{\circ} 47^{\prime}\right.$ and $63^{\circ} 00^{\prime}$
WGr, $9^{\circ} 19^{\prime}$ and $10^{\circ} 00^{\prime} \mathrm{S}$ ). The climate in this area is $A_{m}$ - topical monsoon according to Köppen Climatic Classification and it presents an average annual precipitation of nearly 2,400 mm, with dry season from June to August and rainy season from December to March, where peaks of $1,300 \mathrm{~mm}$ are registered. The annual temperature average is $26.2^{\circ} \mathrm{C}$ and the relative humidity annual mean is $85 \%$. The topography of the study area, with low hills, reaches at maximum $180 \mathrm{~m}$ above sea level with predominance of Yellow Latosol (Table I).

Open ombrophylus forest is the dominant vegetation type in the region (Projeto... 1978). The survey was carried out in undisturbed upland forest locally known as "terra firme" in three permanent vegetation plots, randomized in an area of 219 ha, each measuring 1,5 ha. Each plot was $100 \mathrm{~m} \times 150 \mathrm{~m}$, subdivided into 30 subplots of $20 \mathrm{~m}$ x $25 \mathrm{~m}$ ( $0.05 \mathrm{ha})$. Total height $(\mathrm{m})$ and diameter at breast height $(\mathrm{dbh}) \geq$ $10 \mathrm{~cm}$ of trees and palms that hosted $H$. flexuosa were evaluated, accordingly to the Amazon non-timber forest products network of EMBRAPA (Kamukaia).

The life-cycle stage of the individuals in this study was categorized as adults, following Balcázar-Vargas et al. (2011), as having upper height $\geq 10 \mathrm{~m}$. All the adult plants of $H$. flexuosa were identified in the entire plot and tagged for future management test purposes. The trees of the entire forest community had already been tagged for monitoring growth (Vieira et al. 2002).

TABLE I

Edafoclimatic conditions of site with naturally occurrence of $\boldsymbol{H}$. flexuosa in Rondônia State, Brazilian Amazon (Source: Rondônia 2005, Miranda et al. 2002).

\begin{tabular}{llll}
\hline - Localization: & $61^{\circ} 47^{\prime}$ and $63^{\circ} 00^{\prime} \mathrm{WGr}$ & - Rainfall $(\mathrm{mm}):$ & 2,390 - annual mean \\
& $9^{\circ} 19^{\prime}$ and $10^{\circ} 00^{\prime} \mathrm{S}$ & & \\
- Study area: & 219 ha - primary forest & - Dry season: & June to August \\
- Climate1: & $\mathrm{A}_{m}$ - tropical monsoon & - Rainy season: & December to March (1300mm) \\
- Temperature: & $26.2^{\circ} \mathrm{C}$ - annual mean & - Soil: & Yellow Latosol \\
- Relative humidity: & $85 \%$ - annual mean & - Altitude/Relief: & $180 \mathrm{~m}$ above sea level/Smooth \\
\hline
\end{tabular}

${ }^{1}$ Köppen Climatic Classification 
For each H. flexuosa host tree the upper height was taken with a measuring tape and climbing techniques were used to reach the plant when needed. The $\mathrm{dbh} \geq 10 \mathrm{~cm}$ of host trees was also taken. Furthermore, the crown attributes of each host tree were evaluated following Synnott (1979) for crown form (perfect, good, tolerable, poor, and very poor) with adaptions for crown position (dominant, co-dominant, intermediate, and suppressed). The presence of adult $H$. flexuosa in the stem, crown, or crown and stem, and the current stage of infestation by other lianas (without liana, presence up to $25 \%$, up to $75 \%$, above $75 \%$ ) were also considered.

The botanical identification of the species in this study was done in a first moment based on the experience of a field assistant ("mateiro"), and later by comparison with exsiccates deposited at the herbarium of Embrapa Amazônia Oriental (CPATU), in Pará State.

\section{STATISTICAL ANALYSIS}

Descriptive statistics (Brower and Zar 1984) with significance level at $99 \%$ were used to test differences among the assessed variables. The biodiversity measure among botanical families that host $H$. flexuosa was obtained following Odum (1983):

i) Shannon-Weaver Diversity Index, which takes into account the number and the relative abundance of the species,

$$
H^{\prime}=-\sum_{i=1}^{S} p_{i} \ln p_{i} ; p_{i}=\frac{n_{i}}{N},
$$

where: $p_{i}=$ relative abundance of the $\mathrm{i}$-th species; $N=$ total of individuals of the $\mathrm{n}$-th species; and $S=$ total of species.

ii) Uniformity of Pielou Index, which measures the uniformity defined by the distribution of the species,

$$
e=\frac{H^{\prime}}{\ln S},
$$

where: $H^{\prime}=$ Shannon-Weaver Diversity Index; and $S^{\prime}=$ number of families.
An extensive inventory of the entire forest community was carried out in 2000 at the research station used in the current study (Embrapa in Machadinho do Oeste). The object of the survey was to study the phytosociology, to assess marketable species, and to monitor forest dynamics (Vieira et al. 2002). For comparison of the diversity and uniformity between host trees and the entire forest community the Hutchinson t-test (Zar 1996) was used:

$$
t=\frac{H_{1}^{\prime}+H_{2}^{\prime}}{\sqrt{\hat{\sigma}_{H_{1}}^{2}+\hat{\sigma}_{H_{2}}^{2}}}
$$

The estimator for the variance (a) and the degrees of freedom (b) of the Hutchison t-test is defined by:

$$
\begin{gathered}
\hat{\sigma}_{H}^{2}=\frac{\sum p_{i}\left(\ln p_{i}\right)^{2}+\left[\left(\sum p_{i}\left(\ln p_{i}\right)+\right)^{2} / N\right]}{N^{2}}(\mathrm{a}) \text { and } \\
g l=\frac{\left(\hat{\sigma}_{H_{1}}^{2}+\hat{\sigma}_{H_{2}}^{2}\right)^{2}}{\frac{\left(\hat{\sigma}_{H_{1}}^{2}\right)^{2}}{N_{1}}+\frac{\left(\hat{\sigma}_{H_{2}}^{2}\right)^{2}}{N_{1}}}(\mathrm{~b}),
\end{gathered}
$$

where $N_{1}$ and $N_{2}$ are the number of observations used to obtain the estimative of $N_{1}^{\prime}$ and $N_{2}^{\prime}$.

As for comparison of tree size (dbh) means between host trees and the entire forest community in the survey, F-test (Callegari-Jacques 2003) was used:

$$
z_{\text {calc }}=\frac{\bar{x}-u}{\sigma(\bar{x})},
$$

where ${ }^{\bar{x}}$ is the sample mean, $u$ is the population mean, and $\sigma$ is the standard deviation of the population mean.

\section{RESULTS}

Based on the survey of the three permanent vegetation plots, 403 trees were found (268.66 individuals.ha ${ }^{-1}$ ) distributed into 24 botanical families hosting H. flexuosa alive. Established, adults of $H$. flexuosa were mostly found on the trunk, branches or canopies of natural endemic families such as Lecythidaceae, Burseraceae, Leguminosae, Sapotaceae, Annonaceae, 
Chrysobalanaceae, Apocynaceae, Moraceae, Myristicaceae, and Myrtaceae. Lecythidaceae and Leguminosae constituted $38.05 \%$ of all botanical families surveyed in the study area
(Table II). The species belonging to the main botanical families were: Schweilera coriacea, Protium sp., Licania membranacea, Rollinia exsucca and Pouteria pachycarpa.

TABLE II

Frequency of the host botanical families of $\boldsymbol{H}$. flexuosa in open ombrophylus forest in Machadinho do Oeste, Rondônia.

\begin{tabular}{|c|c|c|c|c|c|}
\hline$\#$ & Botanical Family & $\operatorname{HTC}(\mathrm{n})$ & $\mathrm{FC} \mathrm{(n)}$ & HTC (\%) & $\mathrm{FC}(\%)$ \\
\hline 1. & Lecythidaceae & 115 & 515 & 28.54 & 19.17 \\
\hline 2. & Burseraceae & 61 & 217 & 15.14 & 8.08 \\
\hline 3. & Leguminosae & 45 & 507 & 11.17 & 18.88 \\
\hline 4. & Sapotaceae & 34 & 241 & 8.44 & 8.97 \\
\hline 5. & Annonaceae & 27 & 255 & 6.70 & 9.49 \\
\hline 6. & Chrysobalanaceae & 27 & 94 & 6.70 & 3.50 \\
\hline 7. & Apocynaceae & 21 & 199 & 5.21 & 7.41 \\
\hline 8. & Moraceae & 18 & 223 & 4.47 & 8.30 \\
\hline 9. & Myristicaceae & 13 & 93 & 3.23 & 3.46 \\
\hline 10 & Myrtaceae & 9 & 71 & 2.23 & 2.64 \\
\hline$\ldots$ & Others & 33 & 271 & 8.19 & 10.08 \\
\hline \multicolumn{2}{|c|}{ Total of individuals (n) } & 403 & 2,686 & 100 & 100 \\
\hline \multicolumn{2}{|c|}{ Botanical family (n)/tree community } & 22 & 24 & & \\
\hline \multicolumn{2}{|l|}{$\mathrm{H}^{\prime}$} & $2.34^{\mathrm{ns}}$ & $2.41^{\mathrm{ns}}$ & & \\
\hline \multicolumn{2}{|l|}{$\mathrm{e}$} & 0.757 & 0.760 & & \\
\hline \multicolumn{2}{|c|}{$\mathrm{r}_{(\mathrm{HTC} / \mathrm{FC})}$} & 0.88 & & & \\
\hline
\end{tabular}

ns - not significant by Hutchinson t- test of Shannon-Weaver estimative $(p<0.001)$. HTC - host tree community; FC - entire forest community; $\mathrm{n}$ - number of individuals. H'- Shannon-Weaver Diversity Index; e - Pielou Equability Index; and r - Simple correlation coefficient.

The mean height of hosts was $20.40 \mathrm{~m}$ (SD \pm $6.4 \mathrm{~m}$ ) and only $29.78 \%$ of $H$. flexuosa were found above the mean height; still, in this forest type the vines were found on a wide range of heights ( 0.8 to $33.0 \mathrm{~m}$ height), with $7.2 \mathrm{~m}$ of mean height, independently of the maturity of plants. The canopy in this stratum performs light attenuation to the forest soil. The diameter distribution of host trees of $H$. flexuosa did not differ from that of the entire forest community $>10 \mathrm{~cm} \mathrm{dbh}$ (z-test ${ }_{0.01}=$ 1.96), with mean dbh of $19.55 \mathrm{~cm} \pm 13.64 \mathrm{~cm}$, with $53 \%$ of the adults of $H$. flexuosa climbing up the smallest diameter category of hosts (10.19 to 91.35 $\mathrm{cm} \mathrm{dbh),} \mathrm{and} \mathrm{in} \mathrm{both} \mathrm{the} \mathrm{research} \mathrm{sample} \mathrm{and} \mathrm{the}$ forest community the size distribution showed an inverse J shape (Fig. 1).

Over all crown categories, only $26.05 \%$ of host tree crowns were considered as perfect and good crown (complete or incomplete circle); and tolerable and poor crowns (half-crown or less than halfcrown) together were over $63 \%$ amongst the host tree community, while few host trees showed crowns with any degree due natural damages (Table III).

Regarding position of establishment, $90.82 \%$ of $H$. flexuosa were observed attached to trunks or branches of the hosts. H. flexuosa was less 


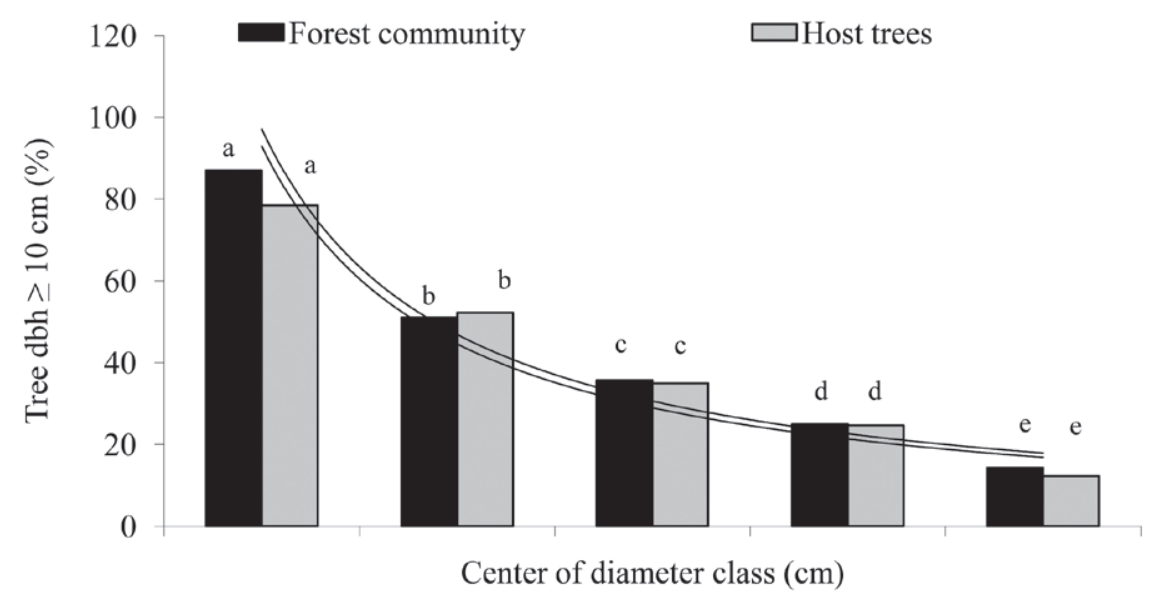

Figure 1 - Tree size (dbh) of open ombrophylus forest with H. flexuosa in Machadinho do Oeste, Rondônia. Common letters indicate means that are not significantly different from one another by Z Test $(p<0.001)$. Source: research data.

observed only in the trunk $(6.15 \%)$ or only in the canopy positions $(3.03 \%)$ and the majority of the vines were growing at a mean height of 10.2 $\mathrm{m}$ of the host trees. Only $23.57 \%$ of crowns were found dominant or co-dominant amongst the host tree community; thus, $41.44 \%$ of hosts presented suppressed crowns; followed by intermediate crowns (36.72\%). Moreover, low frequency of other lianas species $(21.87 \%)$ was found in the same host trees of $H$. flexuosa (Table III).

TABLE III

Crown position and form of host tree community (HTC) of $\boldsymbol{H}$. flexuosa in open ombrophylus forest in Machadinho do Oeste, Rondônia.

\begin{tabular}{cccc}
\hline $\begin{array}{c}\text { Crow } \\
\text { position }\end{array}$ & Individuals (n) & $\begin{array}{c}\text { Crown } \\
\text { form }\end{array}$ & Individuals (n) \\
\hline 1 & $19.00 \mathrm{~b}$ & 1 & $8.66 \mathrm{~b}$ \\
2 & $12.33 \mathrm{~b}$ & 2 & $26.00 \mathrm{ab}$ \\
3 & $49.00 \mathrm{a}$ & 3 & $45.66 \mathrm{a}$ \\
4 & $53.33 \mathrm{a}$ & 4 & $39.66 \mathrm{a}$ \\
& & 5 & $13.66 \mathrm{~b}$ \\
\hline
\end{tabular}

Common letters indicate means that are not significantly different from one another by Tukey Test $(p<0.001)$.

Crow position (illumination): 1 - dominant, 2 - co-dominant, 3 - intermediate and 4 - suppressed. Crown form: 1 - perfect, 2 - good, 3 - tolerable, 4 - poor, and 5 - very poor.
Estimates of host tree family diversity and uniformity by information content are given in Table III. These estimates refer to the sample of 22 families and 403 trees and they were close to that found in the entire forest community of 24 families and 2,686 trees, corroborating that host trees of $H$. flexuosa are important species in the forest type studied.

\section{DISCUSSION}

The majority of $H$. flexuosa adults had climbed up small to medium size host trees in the forest studied, and no specific preference to specific botanical families was found across all the observed forest area. However, the vines were frequently found on the trunk, branches or canopies of natural endemic familiessuchas Lecythidaceae, Burseraceae, Leguminosae, Sapotaceae, Annonaceae, Chrysobalanaceae, Apocynaceae, Moraceae, Myristicaceae, and Myrtaceae. This finding is consistent with the results of other studies on host tree characteristics of Heteropsis genus along the areas of East and Central Amazon (Plowden et al. 2003, Morais 2008) that showed Lecythidaceae, Chrysobalanaceae and Burseraceae as the main families associated with Heteropsis spp. The authors suggested that this fact 
may be explained as Heteropsis spp. could colonize a variety of tree species in ombrophylus forests, mainly those trees with thick and deep longitudinal fissured barks (Morais 2008), as occurred in Machadinho do Oeste.

Most of the adults of $H$. flexuosa in the area tended to be less frequent in taller host trees. In fact, adult $H$. flexuosa in Machadinho do Oeste occurred on a lower range of hosts between $20.0-95.0 \mathrm{~cm}$ $\mathrm{dbh}$ and on a higher range of trees and palms with $10.0-20.0 \mathrm{~cm} \mathrm{dbh}$. These results are similar to those of Plowden et al. (2003), which observed most $H$. flexuosa in host trees from $10.5 \mathrm{~m}$ and above in Brazil; and they differ from those in Balcázar-Vargas et al. (2011) and Knab-Vispo et al. (2003) that found Heteropsis spp. in large trees with $\mathrm{dbh}>20 \mathrm{~cm}$ in "terra firme" forest in Colombia and Venezuela, respectively. However, indicates, as in Knab-Vispo et al. (2003), that the species has a preference for abiotic characteristics of the forest type rather than the density of preferred host tree species or sizes.

The tree size (dbh) did not influence H. flexuosa colonization in the forest community and just like in Balcázar-Vargas et al. (2011), the diameter distributions showed clear inverse J shapes.

Crown form and position, which reflect the light conditions prevailing at a particular moment in the forest canopy (Synnott 1979), or the tree ability to access light resources (Kainer et al. 2007), are important to explain several ecological processes including variations in fruit production and photosynthesis. The findings for host tree attributes are consistent with the results of the study on growth and management of H. flexuosa in "terra firme" forest of Amapá State (Pereira and Guedes 2008), which have climbed host trees from $11.8 \mathrm{~m}$ $\pm 0.8 \mathrm{~m}$ up to $14.3 \mathrm{~m} \pm 0.8 \mathrm{~m}$ of mean height.

Concerning the ability to compete for light, nutrients and water, the scarcity of other lianas species in the same host trees as H. flexuosa $(21.87 \%)$ could indicate a minimum competitive niche, or that those other lianas were not adapted to the abiotic traits at the mean height colonized by $H$. flexuosa (Table III). The diversity indexes followed the expected range in the region (Fotopoulos 2006, Silva and Bentes-Gama 2008), suggesting that H. flexuosa has a random preference pattern for its host trees, or, as in Knab-Vispo et al. (2003), that the simply distribution of preferred host tree sizes could not explain its distribution and density. These results highlight the importance of identifying which habitat type is suitable to support H. flexuosa populations, to recommend future sustainable harvest guidelines for the species in open ombrophylus forest in the Amazon.

\section{CONCLUSION}

- H. flexuosa did not present specific host preferences for developing the capacity to hold itself upright, but was frequently associated with botanical families (Burseraceae, Leguminosae, Sapotaceae, Annonaceae, Chrysobalanaceae, Apocynaceae, Moraceae and Myristicaceae) and species with thick bark (Schweilera coriacea, Protium sp. and Licania membranaceae) of common frequency in the study area.

- H. flexuosa was less frequent with taller and broader trees in the study community.

- Crown form and position were important explanatory variables in this study and indicated the species preference for developing under understory strata light condition.

- Trunks or branches of host trees were the prefered position for the attaching of $H$. flexuosa (90.83\%).

- The low frequency of other lianas (21.87\%) observed on host trees indicated that they could not be adapted to the abiotic characteristics at the mean height colonized by $H$. flexuosa .

- These results highlight the importance of identifying which habitat type is suitable to support H. flexuosa populations, to recommend future sustainable harvest guidelines for the species in open ombrophylus forest in the Amazon. 


\section{ACKNOWLEDGMENTS}

The authors thank members and partners of the Research Network for non-wood forest products of Embrapa (Kamukaia) for all the efforts to make it possible to research this theme. This research was also supported by scholarships of EMBRAPA/Ministério da Ciência e TecnologiaConselho Nacional de Desenvolvimento Científico e Tecnológico (MCT-CNPq) from 2006 to 2008.

\section{RESUMO}

O objetivo deste estudo foi caracterizar a estrutura florestal com H. flexuosa no Estado de Rondônia, como base para a coleta sustentável e diretrizes de conservação da espécie. Os atributos de copa, altura total (m) e o diâmetro a altura do peito $\geq 10(\mathrm{~cm})$ de árvores e palmeiras com H. flexuosa foram avaliados em três parcelas permanentes $(100 \mathrm{~m}$ x 150 m cada), aleatorizadas em 219 ha. Um total de 22 famílias botânicas foram hospedeiras de $H$. flexuosa. Não foi observada preferencia específica para desenvolver sua capacidade de sustentar a si mesma. Entretanto, a espécie esteve frequentemente associada às famílias Burseraceae, Leguminosae, Sapotaceae, Annonaceae, Chrysobalanaceae e espécies que apresentam a casca espessa, como Schweilera coriacea, Protium sp. e Licania membranaceae. A espécie ocorreu com menos frequência conforme o aumento das classes de altura e diâmetro e tendeu a desenvolver-se sob a condição de luminosidade de sub-bosque. Os troncos ou galhos foram o principal local de fixação de $H$. flexuosa (90.83\%) e uma baixa frequência de outras espécies de cipós foi observada nas mesmas árvores hospedeiras. Estes resultados indicam a necessidade de promover práticas de manejo apropriadas para a coleta de raízes e a conservação da espécie em habitat de Floresta Ombrófila Aberta.

Palavras-chave: produto florestal não-madeireiro, ecologia, fibras vegetais, preferência de habitat, manejo florestal de uso-múltiplo.

\section{REFERENCES}

ALMEIDA LS. 2010. Produtos florestais não madeireiros em área manejada: análise de uma comunidade na região de influência da BR 163, Santarém, Estado do Pará. (Dissertação. Mestrado em Ciências Florestais). Universidade Federal Rural da Amazônia, Belém, 128 p. (Unpublished).
AMAPÁ (ESTADO). 2001. Lei n ${ }^{\circ} 0631$, de 21 de novembro de 2001, dispõe sobre procedimentos para a extração e transporte de espécies vegetais produtoras de fibras tipo cipó titica (Heteropsis spp), cipó cebolão (Clusia spp) e similares em todo o estado do Amapá. Diário Oficial do Estado, Macapá, n. 2669, de 21.11.01. On line< http://www. al.ap.gov.br/PL021A01.htm>. Accessed in: 19 Sep. 2008.

AMAZONAS (ESTADO). 2008. Instrução Normativa $n^{\circ}$ 001, de 11 de Fevereiro de 2008, regula a coleta do cipótitica (Heteropsis flexuosa), cipó timbó-açú ou titicão (Heteropsis jenmanii) e cipó-ambé (Philodendron sp.) com procedimentos básicos relativos à utilização sustentável da espécie no Estado do Amazonas, tendo em vista as práticas já adotadas pelos extrativistas e os resultados das pesquisas científicas. On line $<$ www.sds. am.gov.br/index.php >. Accessed in 14 Jun. 2008.

BALCÁZAR-VARgAS MP, PEÑUEla-MORA MC, VAN ANDEL TR AND ZUIDEMA PA. 2011. The quest for a suitable host: size distributions of host trees and secondary hemiepiphytes search strategy. Biotropica 44(1): 1-8.

BALCÁZAR-VARGAS MP AND VAN ANDEL TR. 2005. The use of hemiepiphytes as craft fibres by indigenous communities in the Colombian Amazon. Ethnobotany Research \& Applications 3: 243-260.

BROWER JE AND ZAR JH. 1984. Field and laboratory methods for general ecology. Dubuque: W. M. C. Brow, $226 \mathrm{p}$.

CALlegari-JACQUES MS. 2003. Bioestatística: princípios e aplicações. Porto Alegre: Artmed, 255 p.

DiÁRIO OFICIAL DO EsTADO DE RONDÔNIA. 2010. Nº 1.570 de 09 de setembro de 2010, 76 p. On line $<$ http://www. diof.ro.gov.br/doe/doe_09_09_10.pdf $>$. Accessed in 15 Jan. 2011.

FEARNSIDE PM. 2008. Amazon Forest maintenance as a source of environmental services. An Acad Bras Cienc 80(1): 101-114.

Fotopoulos IG. 2006. Fitossociologia de um trecho da floresta de terra firme na Amazônia Ocidental - Terra Indígena Nove de Janeiro/AM, Brasil. (Dissertação. Mestrado em Desenvolvimento Regional). Universidade Federal de Rondônia, Porto Velho, 57 p.

Guariguata Mr, Fernandes CG, SHeIL D, NASI R, HerreroJAUREgui C, CRONKLETON P AND INGRAM V. 2010. Compatibility of timber and non-timber forest product management in natural tropical forests: Perspectives, challenges, and opportunities. For Ecol and Manag 250: 244-245.

IBGE. 2005. Produção da extração vegetal da silvicultura: 2005. Rio de Janeiro, 2005. v. 20, 47 p. (Série Brasil). On line <http://www.ibge.com.br/home/presidencia/noticias/ noticia visualiza $>$. Accessed in 15 Oct. 2005.

KAINER, KA, WADT LHO AND STAUDHAMMER CL. 2007. Explaining variation in Brazil nut fruit production. For Ecol Manag 259: 245-255.

Knab-Vispo C, Hoffmann B, Moermond T and Vispo C. 2003. Ecological observations on Heteropsis spp. (Araceae) in Southern Venezuela. Econ Bot 57: 345-353. 
LEONI JM AND MARQueS TS. 2008. Conhecimento de artesãos sobre plantas utilizadas na produção de artefatos - Reserva de Desenvolvimento Sustentável Amanã - AM. Uakari 4(2): 67-77.

Marques lC, Pieri C, Roman-Júnior W, CARdoso MLC Milaneze-GutierRe MAND Mello AJCP. 2007. Controle farmacognóstico das raízes de Heteropterys aphrodisiaca O. Mach. (Malpighiaceae). Rev bras farmacogn 17(4): 604-615.

Miranda EE, Mangabeira JADC, Batistella M AND DORADO AJ. 2002. Diagnóstico agroecológico e socioeconômico dos produtores rurais de Machadinho d'Oeste-RO em 1999. Campinas: Embrapa Monitoramento por Satélite, 87 p. (Embrapa Monitoramento por Satélite, Documentos, 18).

Monteiro SN, Aquino RCMP, Lopes FPD, CARVAlho EA AND D'AlmeIDA JRM. 2006a. Comportamento mecânico e características estruturais de compósitos poliméricos reforçados com fibras contínuas e alinhadas de curauá. Matéria 11(3): 197-203.

MonTEIRo SN, Aquino RCMP, LOPES FPD AND D'AlMEIDA, JRM. 2006b. Tenacidade ao entalhe por impacto Charpy de compósitos de poliéster reforçados com fibras de piaçava. Matéria 11(3): 204-210.

MORAIS MLCS. 2008. Sistemática e ecologia de Heteropsis Kunth (HBK) (Araceae Juss.) com destaque especial nas espécies ocorrente na Reserva Florestal Adolpho Ducke - Amazonas, Brasil. (Tese. Doutorado em Ciências Biológicas). Instituto Nacional de Pesquisas da Amazônia, Manaus, $206 \mathrm{p}$.

ODUM EP. 1983. Ecologia. Rio de Janeiro: Guanabara Koogan, $434 \mathrm{p}$.

Pereira JF AND Guedes MC. 2008. Crescimento de raízes e sanidade de Cipó-titica (Heteropsis flexuosa) submetido à exploração no Estado do Amapá. In: Seminário do Projeto Kamukaia: Manejo Sustentável de Produtos Florestais Não-madeireiros na Amazônia, 1., 2008, Rio Branco, AC. Anais... Rio Branco, AC: Embrapa Acre, p.143-150.
Plowden C, Uhl C AND OliveIRA FD. 2003. The ecology and harvest potential of titica vine roots (Heteropsis flexuosa: Araceae) in the eastern Brazilian Amazon. Forest Ecol Manag 1-3(182): 59-73.

Projeto Radam-Brasil. 1978. Folha sc. 20 Porto Velho. Rio de Janeiro, v.16, 668 p. (Levantamento dos Recursos Naturais, 12).

RONDÔNIA (ESTADO). 2003. Boletim Climatológico de Rondônia: ano 2003. 2005. Porto Velho: Secretaria de Estado de Desenvolvimento Ambiental, $32 \mathrm{p}$.

SHANLEY P, LUZ L AND SWINGLAND IR. 2002. The faint promise of a distant market: a survey of Belem's trade in nontimber forest products. Biodivers Conserv 11: 615-636.

SiLva APFF AND BENTES-GAMA MM. 2008. Fitossociologia de uma Floresta Ombrófila Aberta em área de assentamento rural no distrito de Jaci Paraná, Porto Velho, Rondônia. Ambiência 4(3): 435-452.

Summers PM, Browderb JO AND Pedlowski MA. 2004. Tropical forest management and silvicultural practices by small farmers in the Brazilian Amazon: recent farm-level evidence from Rondônia. For Ecol Manag 192: 161-177.

SYNNOTT TJ. 1979. A manual of permanent sample plot procedures for tropical rainforests. Oxford: Common Wealth Forestry Institute-University of Oxford. (Tropical Forestry Papers, 14).

Vieira A, Martins EP, Silveira ALP, PeQueno PLL AND LOCATELLI M. 2002. Fitossociologia de um fragmento florestal na região de Machadinho d'Oeste, RO. Porto Velho: Embrapa Rondônia, 16 p. (Embrapa Rondônia, Documentos, 9).

ZAMBrana NYP, BYG A, SVEnNING JC, Moraes M, GRANDEZ C AND BALSLEV H. 2007. Diversity of palm uses in the western Amazon. Biodivers Conserv 16: 2771-2787.

ZAR JH. 1996. Biostatistical analysis. $3^{\text {rd }}$ ed., New Jersey, Prentice-Hall, 662 p. 